\title{
The Death Collectors: The Material Culture of War as a Means of Reclaiming Agency in Eastern Ukraine
}

\author{
ALISA SOPOVA \\ Harvard University
}

\section{Introduction}

Irina takes out of her handbag a small jewellery box, white with gold rim and stucco red roses on top. She opens it and lays out the contents on her palm - five pieces of artillery shrapnel, thick black scraps of metal with sharp edges. The largest one is approximately the size of Irina's thumb; smaller pieces are closer to the rings she is wearing.

Irina's apartment has suffered from shelling in August 2014. A shell landed in front of the building, as shrapnel flew inside breaking the window and the balcony door, cutting wallpaper and getting stuck in the ceiling. Irina herself was hiding in the bathroom. She had just entered with grocery bags when she heard the explosion and saw a ball of fire coming out of the kitchen window. Her first reflex was to jump into the bathroom: people who live in the war zone in eastern Ukraine know that a windowless room (usually the bathroom) is the safest place in the house. When the shelling ended, Irina went out and looked out of the broken window. The land in front of the building was littered with dead birds killed by the explosion.

While cleaning up the aftermath, Irina found five pieces of shrapnel in her bedroom and living room. She took a picture of them (Figure 1) and posted on her social media feed with a caption 'A piece of happiness to every house.' Four years after the incident, Irina still keeps her 'pieces of happiness' in a jewellery box. She says one day she is going to make a chaplet out of them.

Irina is a young professional woman living in Donetsk, the largest city controlled by separatists and proclaimed as their capital. A few days after talking to her I travelled to 
Novgorodskoe, a small settlement on the government-controlled side of the conflict. A street at the eastern edge of the village runs right into the frontline a few hundred meters away. All the fences here are covered with small holes left by shrapnel, a sign that shelling is a regular occurrence here. Most people still living here are

elders who refuse to leave their homes. One woman brings out of her house something wrapped into a handkerchief. She unwraps it and shows me two pieces of shrapnel and a bullet case. This is her little collection.

Almost everyone here has one. Shrapnel and bullet cases are being kept in drawers and caskets, or simply in open display. When people find objects too large to keep at home, they often bring them to the local authorities. The closer to the frontline, the bigger the collections.

Novgorodskoe, a home to twelve thousand people, a phenol plant and a railway junction, has a frontline running through its eastern border. About 100 houses were damaged here during the war. The mayor's office looks like an impromptu museum (Figure 2). It was renovated not long before the war has started, with walls painted in a warm apricot colour and windows covered with terracotta blinds. In the corner across the mayor's table stands a large floor vase with ears of wheat. Next to it, several exhibited artefacts present the history of the settlement, including clay roof tiles with XIX-century imprints. The remaining, largest part of the exhibition is devoted to the artefacts of the current war. There are cases from the rocket-propelled grenade launchers, tails of mortar shells, reactive rocket engines, and a large metal pipe - a case from a reactive artillery shell. Dozens of pieces of shrapnel lay on windowsills.

During four years of fieldwork in the war-torn eastern Ukrainian region of Donbass, I have seen countless collections of pieces of ammunition. Since the outbreak of the conflict in 2014 , a culture of collecting and preserving the artefacts of the ongoing war has spontaneously formed. To understand the phenomenon, I argue it is best to contextualize it in the broader processes of everyday life in the war zone. 


\section{What kinds of objects (matériel) are we talking about?}

The most popular object for collecting is shrapnel. It usually comes from the shells of BM21 multiple rocket launchers, also known as Grad (Hail). This weapon is a modern modification of a widely-known Soviet artillery system named Katyusha. Introduced by the Red Army during World War II, Katyusha is believed to have played a crucial role in their victory. Folklore and propaganda have given it a cult status: Katyusha is a 'character' of popular war songs and is recognized even by people who don't know anything else about weapons.

Its descendant, Grad, is also famous in popular culture, but for other reasons. This truckmounted launcher fires 40 shells of $122 \mathrm{~mm}$ calibre in a span of 20 seconds. Its firing range is between 20 and 40 kilometres ${ }^{1}$. Upon reaching its destination, every shell explodes into 3,000 to 4,000 pieces of shrapnel, each with a high damaging ability.

Grad has low precision because its aim is to affect a large territory. This makes it efficient in large-scale battles - and highly indiscriminate in its damage. Such launchers are not supposed to be deployed anywhere near civilian-populated areas. However (and this earns it its reputation), due to its affordability, availability and efficiency, Grad has notoriously been used in every postSoviet war, often fired at densely-populated cities. Its rockets are not recognized by the air-raid warning systems, and, true to its name, it often falls on the streets from the blue sky, killing everything in the proximity. In the context of the war in Donbass, Grad shelling accounts for many of the civilian casualties ${ }^{2}$.

Pieces of shrapnel - the most ubiquitous and deadly material objects of this war - are the primary collection commodity. They range in size approximately from one to ten centimetres and

\footnotetext{
${ }^{1}$ Manufacturer, Splav Rocket. Reaktivnaia sistema zalpovogo ognia «Grad» (2016), $<$ http://splav.org/v3/grad.asp> [accessed 23 November 2018].

2 OSCE Special Monitoring Mission to Ukraine, Civilian casualties in eastern Ukraine 2016 (2017), $<$ https://www.osce.org/special-monitoring-mission-to-ukraine/342121?download=true> [accessed 23 November 2018], p. 1.
} 
have very sharp edges (Figure 3). When I first saw shrapnel in the wake of war, my colleague who had previous experience covering armed conflicts told me: 'Touch it. Do you feel how sharp the edges are? It is designed to tear your body apart.' When I first saw the bodies of people killed by shelling later that summer, I understood what he meant. Human flesh blown inside out is terrifying and looks completely different from any other wound.

Other collected weaponry pieces included bullet cases (most often from Kalashnikov rifles), propeller-like tails of mortar shells, and shell cases from automatic cannons of BMP armoured vehicles.

\section{Gaining a symbolic power}

These remains of materiel have no material value. They are neither beautiful nor pleasant in any sense. However, existing studies of collecting and collections shed some light on the ways this activity can acquire a deep meaning.

In the studies of materiality, collecting is theorised in relation to control and power. According to Pearce, 'we can control our collections as we can few other matters in this world ... and the ground of this control rests in our ability to select or discard items for inclusion in our collections, and then to manipulate those which we choose as we wish.' In a situation when one's life and death is highly dependent on the random hits of shells, collecting pieces of these shells might be seen as a way to symbolically regain control by acquiring a physical ownership over these deadly objects.

This ownership allows for empowerment far exceeding mere possession. The concept of decontextualization/recontextualization ${ }^{4}$ views collecting as a 'world-making' activity through which objects 'become temporally anchored in the collection rather than in their individual pre-collection

\footnotetext{
${ }^{3}$ Susan Pearce, An investigation into collecting in the European tradition (London: Routledge, 1995), p. 178.

${ }^{4}$ Brenda Danet and Tamar Katriel, 'Glorious obsessions, passionate lovers, and hidden treasures: collecting, metaphor, and the romantic ethic,' in The Socialness of Things: Essays on the Socio-Semiotics of Objects, ed. By Stephen Harold Riggins (Berlin, New York: Mouton de Gruyter, 1994), pp. 23-62 (p. 28). 
histories'. In other words, through being gathered, reordered and placed in a designated spot like a casket or a shelf, pieces of shrapnel are deprived of their deadly unpredictability and relegated to the mere elements of the room interior.

This phenomenon is not unique to eastern Ukraine. Moshenska ${ }^{5}$ describes children in British cities and towns collecting shrapnel after air raids during the Blitz. Building on Belk et al. (1988), she suggests that 'these practices had something to do with gaining power over the material culture that was killing and injuring so many people ${ }^{6}$.

Furthermore, collecting pieces of armament constitutes 'dealing with trauma' by introducing an element of order into the chaotic reality of a war zone. Danet and Katriel characterize it as 'the systemic organization and the striving for closure as order-producing elements of collecting activities. ${ }^{7}$ Pearce notes that collections act as 'a structuring principle in their [collectors'] lives. ${ }^{8}$ Therefore, she suggests that collecting is an activity that helps people get through transition periods of life such as adolescence or recovery from a cancer surgery?.

Uniting these concepts into a single, war-driven narrative, Moshenska suggests that 'shrapnel collecting might have been above all a coping mechanism, a means for children to control or domesticate the material culture of violence by integrating it into their social practices and thereby negating its violent and alien qualities. ${ }^{, 10}$

These studies provide the framework for approaching 'death collecting' as an activity that helps its subjects to cope with their traumatic experiences by gaining symbolic power over the very objects that nearly killed them.

In this context it is worth noting that, according to my observations, people mostly engage with matériel that they find inside and in the immediate proximity to their home or work space.

\footnotetext{
${ }^{5}$ Gabriel Moshenska, 'A hard rain: children's shrapnel collections in the Second World War', Journal of material culture, 13.1 (2008), 107-125.

${ }^{6}$ Moshenska, p. 121.

${ }^{7}$ Danet and Katriel, p. 30.

${ }^{8}$ Pearce, p. 237.

${ }^{9}$ Pearce, pp. 237-238.

${ }^{10}$ Moshenska, p. 109. 
Unlike any random piece of armament out there, these particular shrapnel bits that invaded their personal space and could have killed them fascinate people all the more.

Surprisingly, collectionner-enthusiasts actively sought me out when I posted insights from my fieldwork in Donbass on social media. In summer 2018, I wrote a Facebook post briefly describing the phenomenon of shrapnel-assembling. In response, I received a comment from a journalist who lives and works in Yemen. She wrote:

'I used to do the same. Collect all the pieces of bomb remnants that landed on my roof after air strikes in the neighbourhood. In September 2015 they were pretty much every night. Every morning I'd go shrapnel hunting on the roof. Kept them on my desk. I've never thought about why. But yes, I think part of it was a [middle finger symbol] you, we made it through the night.'

While the reflection on the experience of someone in Yemen cannot be directly applied to eastern Ukraine, the concurrence of gathering those pieces of shrapnel that directly endangered the collector reinforce the theme of celebration of one's survival and triumph over a near-death experience at the hands of a fragment.

\section{Weapons turned monuments: Second World War legacy}

Ivan Ivanovich (he introduced himself with his patronymic, a way to address older people, even though he doesn't look older than 40) is a commander at a checkpoint on the main road to Donetsk from the North-West. Actually, it is almost at the entrance to this enemy-controlled city. During the heavy fighting for Donetsk Airport just a few kilometres away in winter 2015, it was a main transit point for troops rotating in and out. This road was barely controlled by governmental troops for some time, making it a very dangerous place. The checkpoint itself used to be nearly a constant battlefield for months.

This place has a kind of special, symbolic meaning and is rather popular in the Ukrainian narratives about the war. It is usually referred to as 'Respublika Most' (Republic 'Bridge'). The origins of the 'republic' part in its name are unclear. However, 'bridge' comes from the fact that 
this checkpoint is situated under an overpass that used to be a part of Donetsk's ring road. Now that the warfare is largely stabilized, this place is relatively quiet.

Ivan Ivanovich is a gentle, middle-aged man in glasses, slightly overweight for someone serving at the frontline position. He said he used to live in a village and work as an agronomist. There is something homey and roundish in his looks and movements, reminiscent of Platon Karataev from Tolstoy's $W$ ar and Peace. His conscientious tour-guiding of his environment makes it clear that he views his checkpoint as a place that needs to be cleaned regularly and kept in good order, more like one's home rather than like a military object. He installed sturdy bathrooms and a kitchen at his checkpoint, regularly running a laundry truck.

Ivan Ivanovich collects shrapnel with a clear purpose. He says he plans to donate his collection to volunteers from Lithuania who will melt the shrapnel down into a Christian cross and use it to create a memorial object of this war.

But the singular trophy and pride of Ivan Ivanovich, the crown-jewel treasure of his collection, is a whole military truck (Figure 4) covered with traces of shrapnel hits, already a tad rusty.

Ivan Ivanovich: - Many times they wanted to sell it for scrap metal, but I have preserved it. Author: - Why did you preserve it?

I.I.: - So that everyone knows what they [those who shelled] have done to it.

A: - But this is a military truck, it's a legitimate target, [here I misinterpreted his motivation as collecting evidence of alleged war crimes, an issue that I will describe in more detail in the next chapter].

I.I.: - So what? I just want people to not forget what was happening here. Everything was shelled.

Ivan Ivanovich views the damaged truck as much more than a mere combat loss of Army property: for him, it is a historic artefact possessing the power of immortal memory - an antidote to people 
forgetting the horrors of the war. It is a silent witness of an extraordinary situation that he rescues from oblivion.

There is a great deal of consensus on the role that artefacts-turned-war-monuments play in collective remembering and understanding of conflict. They serve as mediums of war to those who have not experienced it personally; they help to heal collective trauma ${ }^{11}$. They serve as 'touchstones to the past', 'agents of collective memory'12 meant to not only educate the visitor but to also create an emotional engagement with the wartime events. According to Pearce, 'the material nature of the objects means that they, and they alone, have the capacity to carry the past physically into the present. ... The object is, in colloquial speech, the 'real thing'; it has sincerity, validity and authenticity. ${ }^{, 13}$

Turning weapons into museum objects while the war is still ongoing is not uncommon. Gygi $^{14}$ notes that during the First World War the Berlin arsenal began exhibiting war matériel as early as 1914. The exhibition included the remains of an exploded French shell. 'This authentic remnant was the only evidence of the traumatic suddenness of the explosion, which could not be communicated by visual or auditory means, ${ }^{, 15}$ suggests the author.

In the Soviet practice, artefact monuments carried particularly high symbolic value. Based on their direct involvement in historical events, they were classified as 'genuine monuments' (pamyatnik-podlinnik) as opposed to 'symbolic monuments' (pamyatnik-simvol):

\footnotetext{
${ }^{11}$ Zachary Beckstead and others, 'Collective remembering through the materiality and organization of war memorials', Journal of Material Culture, 16.2 (2011), 193-213.

12 John Schofield, 'Monuments and the memories of war: motivations for preserving military sites in England', in Matériel Culture: The Archaeology of Twentieth-Century Conflict, ed. by John Schofield, William Gray Johnson and Colleen Beck (London: Routledge, 2002), pp. 143-158 (p. 144).

${ }^{13}$ Pearce, p. 171.

${ }^{14}$ Fabio Gygi, 'Shattered experiences-recycled relics: Strategies of representation and the legacy of the Great War', in Matters of Conflict, ed. By Nicholas Saunders (New York: Routledge, 2004), pp. $72-89$ (p. 79).

${ }^{15}$ Gygi, p. 79. 
'Genuine monument is a result of historical action; its destruction leads to the loss of real traces of a historical event. A symbolic monument is constructed in memory of an event already after it had taken place, and it does not carry equal historical value. ${ }^{16}$

Such attitude is borne out of the fact that cities and towns of the Western part of the former Soviet Union that experienced the Second World War are full of such 'genuine monuments'. Gigantic material remnants (usually tanks, jets and heavy vehicles leftover from the fighting) are ubiquitous elements of the social landscape. They often serve as sites for the public rituals of commemoration. Newlyweds lay flowers in front of the pedestal while kids climb on top of the tanks. School excursions, youth socializing, and romantic walks routinely gravitate to the squares boasting such monuments.

As the site of some of the harshest battles and highest casualties between 1941 and 1944, Ukraine is home to a great number of WWII military-equipment-turned-monuments. In the Donetsk region alone, there are several dozen large memorial vehicles. One of the most popular adorns the grave of Frantz Grinkevich, a tank division commander during the Red Army's operation to retake Donetsk from the Nazis in 1943. This T-43 tank is believed to have been used by Grinkevich himself before his combat death ${ }^{17}$.

Displays of large military vehicles in eastern Ukraine are usually buttressed by various museums of WWII artefacts, often amateur ones organized by the enthusiasts of the local history in schools and libraries.

This means that people in today's eastern Ukraine grew up and spent most of their lives surrounded by museified artefacts of history's greatest war. This cultural landscape shapes their

\footnotetext{
${ }^{16}$ Igor Kirianov, 'Klassifikatsia, printsipy otbora I vyiavleniya pamiatnikov trudovoi slavy sovetskogo naroda', paper delivered at the conference 'Pamiatniki trudovoi slavy sovetskogo naroda', Gorky, 1979.

${ }^{17}$ Oksana Miheieva, 'Derzhavna ideolohiya ta konstruyuvannya spil'noyi pamyati pro mynule: orhanizovane zabuttya ta fenomen pryhaduvannya (na prykladi pamyatnykiv Donetska)', paper delivered at the conference 'Suchasni suspilni problem u vymiri sotsiolohiyi upravlinnya' (Donetsk National University, 14 April 2006), pp. 178-179.
} 
picture of the world, in this case by providing what amounts to an instruction regarding what to do with spent military equipment: a place in the designated public spaces to serve as a monument, a commemoration, a notice against forgetting what happened.

In the same vain, Moshenska ${ }^{18}$ suggests that being exposed to the souvenirs of the First World War could have influenced the urge of British children to collect shrapnel during the Second World War: 'The display of children's souvenirs of the Second World War would have echoed, perhaps consciously, their adult relatives' souvenirs of the First. It could be argued that this juxtaposition was an attempt by the children to equate their experiences of aerial bombardment with the narratives of adult warfare that they would have been most familiar with.' Whether by children or adults, the transmission of 'how-to' commemorative practices from the past offer a cultural blueprint for understanding, narrativizing, and honouring.

Furthermore, it can be argued that, by attempting to museify war matériel, Ivan Ivanovich and others like him do a little more than simply preserving the established order. It is in the context of a peaceful life that the war artefacts play the role of monuments and showpieces. In the context of war, they are what they were designed to be: weapons. Therefore, placing these objects in the space of monuments rather than acting machines can be viewed as an imposition of a pacifistic context onto them, a symbolic movement towards ending the war. The emotional message, as it were, could be formulated as: 'You don't get to decide what this is for - I do! And I say it's a peacetime object.'

\section{Evidence of Human Rights Violations}

Finally, the material nature of war artefacts allows them to serve as evidence. This may be a storage of war as a historical moment for the future generations to remember (as described in the previous section). But it may also be another, a more practical type of evidence - that of the

\footnotetext{
${ }^{18}$ Moshenska, p. 114. 
human rights violations by the warring sides. The pieces of ammunition collected in the homes and backyards indicate that these civilian sites were targeted or, at best, accidentally hit by indiscriminate weapons. Both are a violation of the International Humanitarian Law, as well as pious proclamations of the commanders and leaders.

Naturally, most of the civilians lack the legal knowledge of what exactly constitutes a violation and where to provide the evidence for investigations. Nevertheless, they have a general understanding that some kind of investigation might ultimately emerge. This expectation - vague as it might have been - was surely aided by the extensive media coverage of the International Criminal Tribunal for the former Yugoslavia, evoking wars took place recently and near Ukraine. People who even partly assign their collections the function of the war crime evidence often referred to them as being preserved 'for Hague.'

The 'Hague evidence' motivation was also encouraged by the propaganda: both warring sides routinely accuse each other of alleged war crimes. While these charges are often cynical and self-serving, their effect is clear. The message is out there, and people get it: war crimes are all around us.

This was especially true during the first year of the conflict, when fighting was perceived more as an exception than a normality. Back then, people were following the news daily, taking sides and expecting a quick denouement. Collecting the evidence of violations seemed like a reasonable thing to do, and many got involved in it. One woman I met in summer 2014 in the town of Slavyansk was preserving in her house large pieces of what she believed was a white phosphorus bomb prohibited for use in populated areas (Figure 5).

Experiences from other conflicts imply that such intentions might have potential to develop into larger action. Saunders ${ }^{19}$ describes cases in Guatemala and Bosnia where local

\footnotetext{
${ }^{19}$ Rebecca Saunders, 'Tell the truth: the archaeology of human rights abuses in Guatemala and the former Yugoslavia' in Matériel Culture: The Archaeology of Twentieth-Century Conflict, ed. by John Schofield, William Gray Johnson and Colleen Beck (London: Routledge, 2002), pp. 103-114. 
grassroot movements initiated archaeological research in the sites of recent violence and found proof of human rights violations. This helped to uncover the truth about what had happened (despite the denials of complicit actors) and provide a closure to the aggrieved communities.

Whether something analogous will ever happen in Ukraine remains unclear. What is evident, however, is that the popular perception of the likelihood changed dramatically as the war proceeded. As the fighting dragged on, the situation on the ground appeared increasingly unfavourable to the explicit investigations. Throughout the four and a half years of trench warfare in Ukraine, the hope for an end to war faded. The aspiration for justice disappeared with the realization that no-one out there cares about what people in eastern Ukraine are being shelled with. Today, the references to the Hague have become a rarity.

However, even though shelling of civilian areas has become normalized, people do preserve the conviction that - in fact - it is not normal at all. They recognize that shrapnel found in their garden is an evidence of the fact that their garden was unlawfully targeted. They concede that nobody seems to care about their suffering for four consecutive years now; but the outside reaction may not necessarily matter at this stage. The simple, undeniable fact of having this tangible evidence an important reality check in itself. As both warring sides deny their part in the abuse of civilians (but dutifully accuse each other), these artefacts symbolically triumph over the mendacity. Gathering and preserving this evidence is a silent protest against the abuse, a narrativization of an ongoing conflict against official lies.

\section{Swords to Ploughshares}

There is a small souvenir stand operating at the Central Market of the separatist capital of Donetsk. It mostly sells China-produced whatnots with the emblem of the self-proclaimed Donetsk People's Republic: flags, pens, mugs, fridge magnets and badges. But the most famous and valued product at this stand is locally produced. It is a forged figurine made out of an armoured vehicle cannon shell case. It usually looks like a normal shell case, but with a metal rose 'growing' 
from the open side of it. In another modification, the case is open lengthwise to form an ashtray, and the rose is attached on the side (Figure 6). These figurines are not industrially produced but handmade by a local blacksmith. The price of one item is about one thousand Russian roubles, or $\$ 20$.

The rose is not random - it is a symbol of Donetsk. In the mid-twentieth century, the local authorities made efforts to counterbalance the image of the city as a Soviet capital of heavy industry. Instead, they promoted the concept of a beautiful city, emphasizing how pleasant life is. Ultimately, the urban facelift resulted in planting large amounts of greenery in the streets and parks, including roses that were promoted to be a symbol of the place. Starting from 1960s, Donetsk was famously referred to as 'a city of million roses', a name not in the least abstract: every spring literally a million rose bushes were planted.

After a brief break in the 1990 s, this tradition was renewed. As Donetsk was preparing to host the Euro 2012 UEFA football championship, a new emblem was developed for the city. It depicted graphic images of a piece of coal and a rose with the caption 'Donetsk: power and beauty' (Figure 7). In this context, the new wartime souvenir is a continuation of the visual tradition, carrying the same message: a fusion of brute force and fragile beauty. However, the new meaning is a little bit different: if the coal and rose used to symbolize the 'two faces' of Donetsk, the rose defiantly growing out of a shell case speaks of resilience and resurrection.

This metal rose is only the most famous example of the creative remodelling of war matériel into decorative items. Every month or so, a mall called 'Continent' in downtown Donetsk hosts a fair of handmade goods. The participants, mostly young women, sell home-produced crafts like jewellery, interior decorations, stuffed toys, soaps, vegan sweets, etc. from lovingly decorated stands. When I visited this fair in May 2017, I discovered a stand advertised as Bullet case jewellery'. It presented pendants, bracelets and earrings inlaid with pieces of bullet cases (Figure 8). The woman who created the bijouterie had no sense whatsoever that this is something unusual or exotic, noting the high demand. 
In the households and military bases throughout the war zone, one finds comparable 'misuses' of military objects, both creative and practical, like a chicken cage made out of weaponry box (Figure 9) or a bullet container turned into a bird feeder (Figure 10).

Stanbridge ${ }^{20}$ describes similar practices in Laos where the local population uses unexploded bombs and artillery shells still scattered from the Vietnam war for multiple purposes. The most popular is gathering them for scrap metal for profit. They are later industrially melted into steel rods used in construction to reinforce concrete - literally turning swords to ploughshares. On a smaller scale, war remnants are used by the resourceful Laotian peasants as support pillars for barns and fences. One picture by the author features a local man who uses an artillery shell as an anvil while making a knife out of shrapnel ${ }^{21}$.

Saunders ${ }^{22}$ takes note of the 'multimedia cultic obsession' with the object of an artillery shell during and after the First World War. He offers examples of both pragmatic and artistic transformations of them, from makeshift gas gongs in the trenches to souvenirs painted and encrusted with great skill. Speaking of the motives of such involvement, he emphasizes the economic profit (producing and selling of such souvenirs by veterans and civilians of devastated areas helped them to make ends meet), but also the deeper concept of recontextualization: 'artillery shell had been the agent of destruction and was transformed physically and symbolically into something economically positive by the people whose lives it had shattered. ${ }^{23}$

There is a consensus among ethnographers of war that the central feature of life in the warzone environment is creativity $\left(\mathrm{Macek}^{24}\right.$, Nordstrom $\left.{ }^{25}\right)$. In order to be able to keep up with their

\footnotetext{
20 Andrew Stanbridge, 'UXO in Laos: A Multifaceted Look at Bombs from the Secret War Era', Anthropology Now, 3.2 (2011), 48-61.

${ }^{21}$ Standbridge, 52.

22 Nicholas Saunders, 'The ironic 'culture of shells' in the Great War and beyond', in Matériel Culture: The Archaeology of Twentieth-Century Conflict, ed. by John Schofield, William Gray Johnson and Colleen Beck (London: Routledge, 2002), pp. 22-40

${ }^{23}$ Saunders, 33.

${ }^{24}$ Ivana Maček, Sarajevo under siege: Anthropology in wartime (Philadelphia: University of Pennsylvania Press, 2009), pp. 34-61.

25 Carolyn Nordstrom, A different kind of war story (Philadelphia: University of Pennsylvania Press, 1997), pp. $12-15$.
} 
wartime experiences and maintain basic functional normality, communities and individuals have to constantly engage in the creative process of reframing and reimagining their reality. In this sense, the acts of physically remaking war objects into jewellery, interior decorations or other items of domestic use is a material manifestation of such creativity. Therefore, turning the murderous objects of war into peaceful domestic items could be viewed as an act of social processing of wartime reality into a more normalized everyday discourse.

\section{Conclusion}

The existing literature on the anthropology of war indicates that people who live in zones of armed conflicts generally tend to engage with material objects of war. However, most of the cases go as far back as to the First and Second World Wars. Studies of material culture of modern conflicts are deficient - partly due to an over-emphasis on the cyber-meanings in contemporary conflicts. In this sense, the war in Ukraine is of particular interest, not only as modern but ongoing. The conflict demonstrates the versatile practices connected with material nature of munitions.

The studies of civilian engagement with war matériel tend to focus on the rather narrow aspects of this engagement, such as children's collecting practices (Moshenska) or the economic profit (Standbridge, Saunders). I have argued that the re-appropriation of objects of war for peaceful means is part of a more complex and multidimensional phenomenon - just as symbolic as narrowly economic.

Such collecting is a means of acquiring symbolic power over deadly objects and restoring an element of order into the chaos of war. In the context of the tradition prevalent in the postSoviet countries of commemorating past wars with 'genuine monuments' (preserved artefacts of war), the engagement with the artefacts of the current conflict represents a re-enactment of previous cultural decisions. Weapons are, so to speak, put in their place: they are consigned to 
where they are supposed to be in a peaceful discourse, the space of monuments, memory, and predictability. Building upon the concept of war artefacts as witnesses of real-life events, I also suggested the that collecting them is an effort to evidence human rights abuses. While civilians in eastern Ukraine understandably lack trust in the official institutions and fair investigations, they cherish this proof of their own, an alternative narrative of the war that challenges the conventional one. Finally, I examined the practice of physically turning the pieces of armament into art and household items as a manifestation of creativity and the affirmation of the vitality of life in the war zone - an act of reinterpretation of the reality of war into a peaceful discourse.

Through the engagement with the material objects of war, people in Donbass attempt to symbolically regain agency and control over their situation. While their lives and deaths depend on the cruel whim of a random shell hitting their neighbourhood, they seek activities that allow them to feel like active subjects rather than passive objects. These actions, whether practically efficient or not, create an alternative symbolic framework and preserve dignity. 


\section{List of figures}

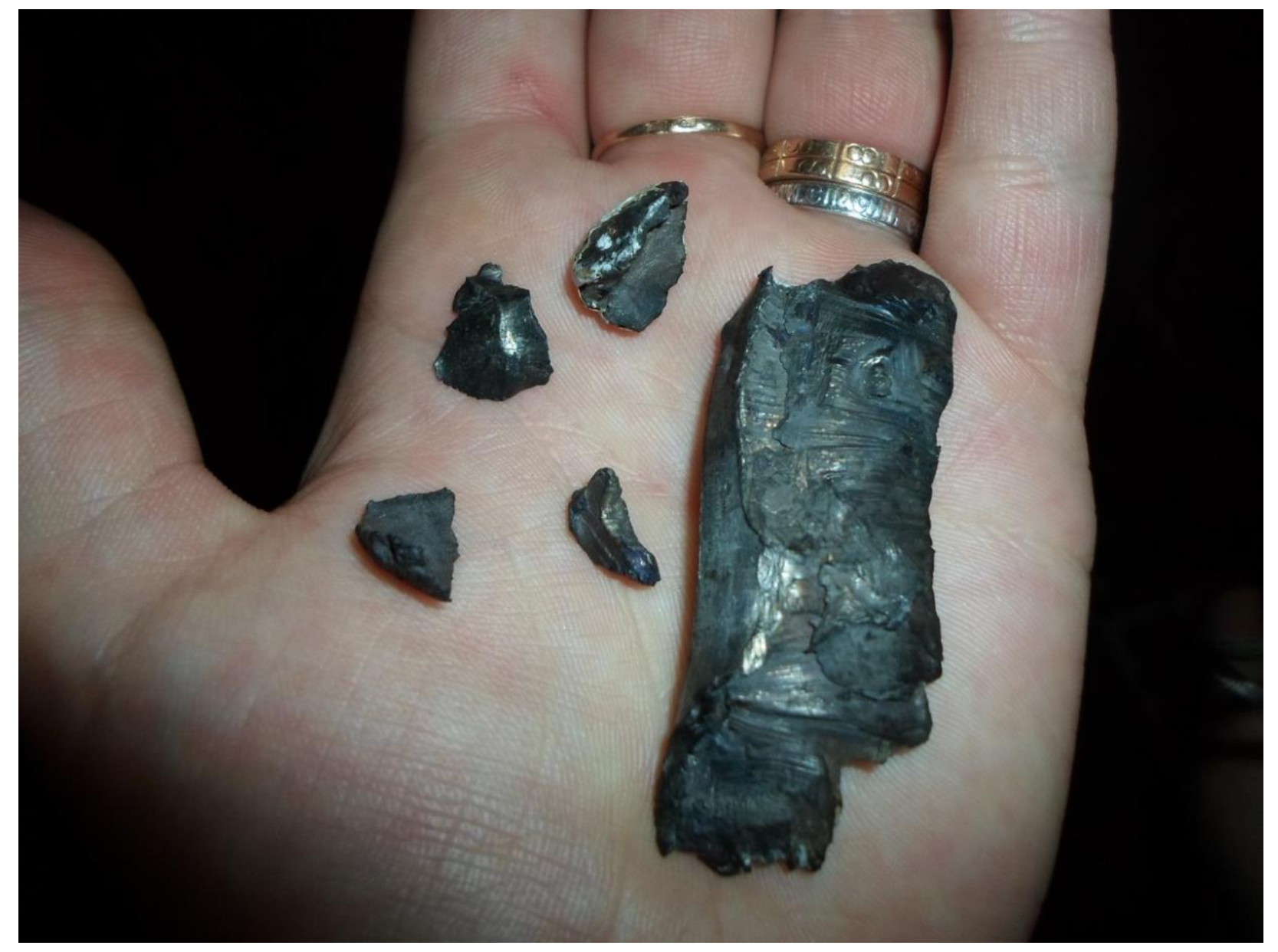

Figure 1. Irina holds pieces of artillery shrapnel that she has gathered in her apartment in downtown Donetsk after shelling and preserves in jewellery box (Credit: Irina’s social media feed). 
SOPOVA - THE DEATH COLLECTORS: THE MATERLAL CULTURE OF W AR AS A MEANS OF RECLAIMING AGENCY IN EASTERN UKRAINE

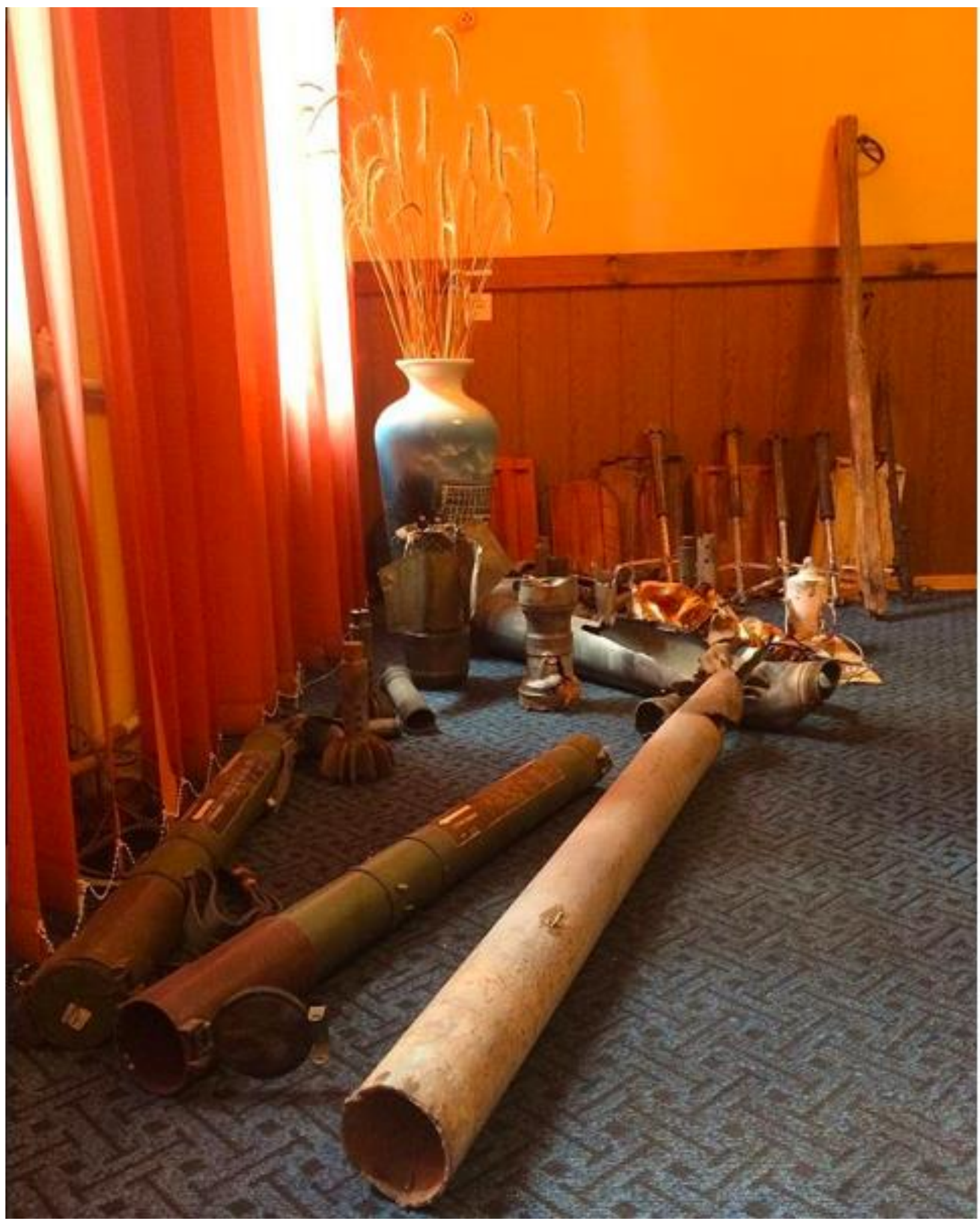

Figure 2. Impromptu museum of ammunition in the mayor's office in Novgorodskoe (Credit: author). 


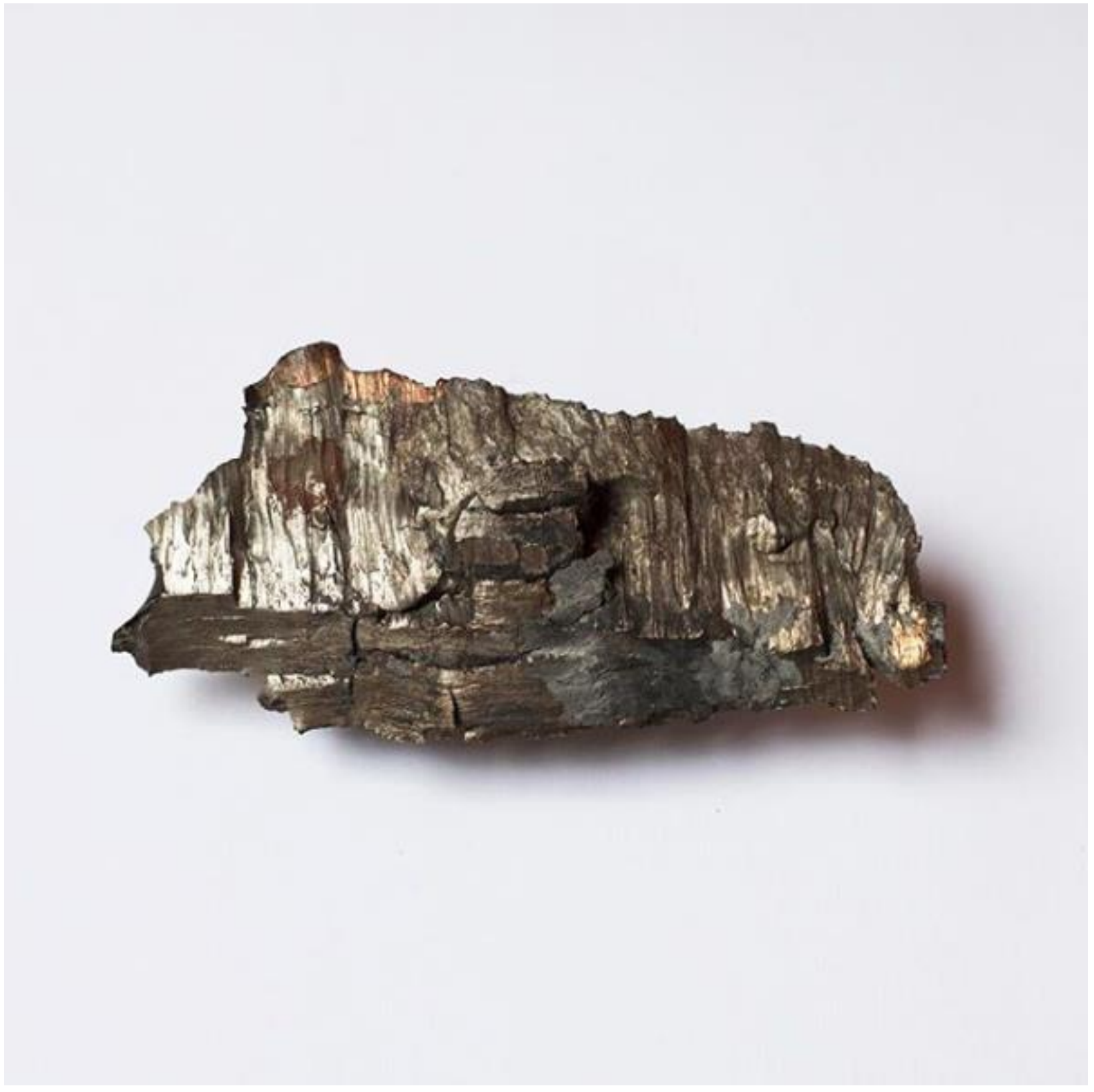

Figure 3. A piece of shrapnel from Grad shell is the most widespread collecting item (Credit: Anastasia Taylor-Lind). 
SOPOVA - THE DEATH COLLECTORS: THE MATERLAL CULTURE OF W AR AS A MEANS OF RECLAIMING AGENCY IN EASTERN UKRAINE

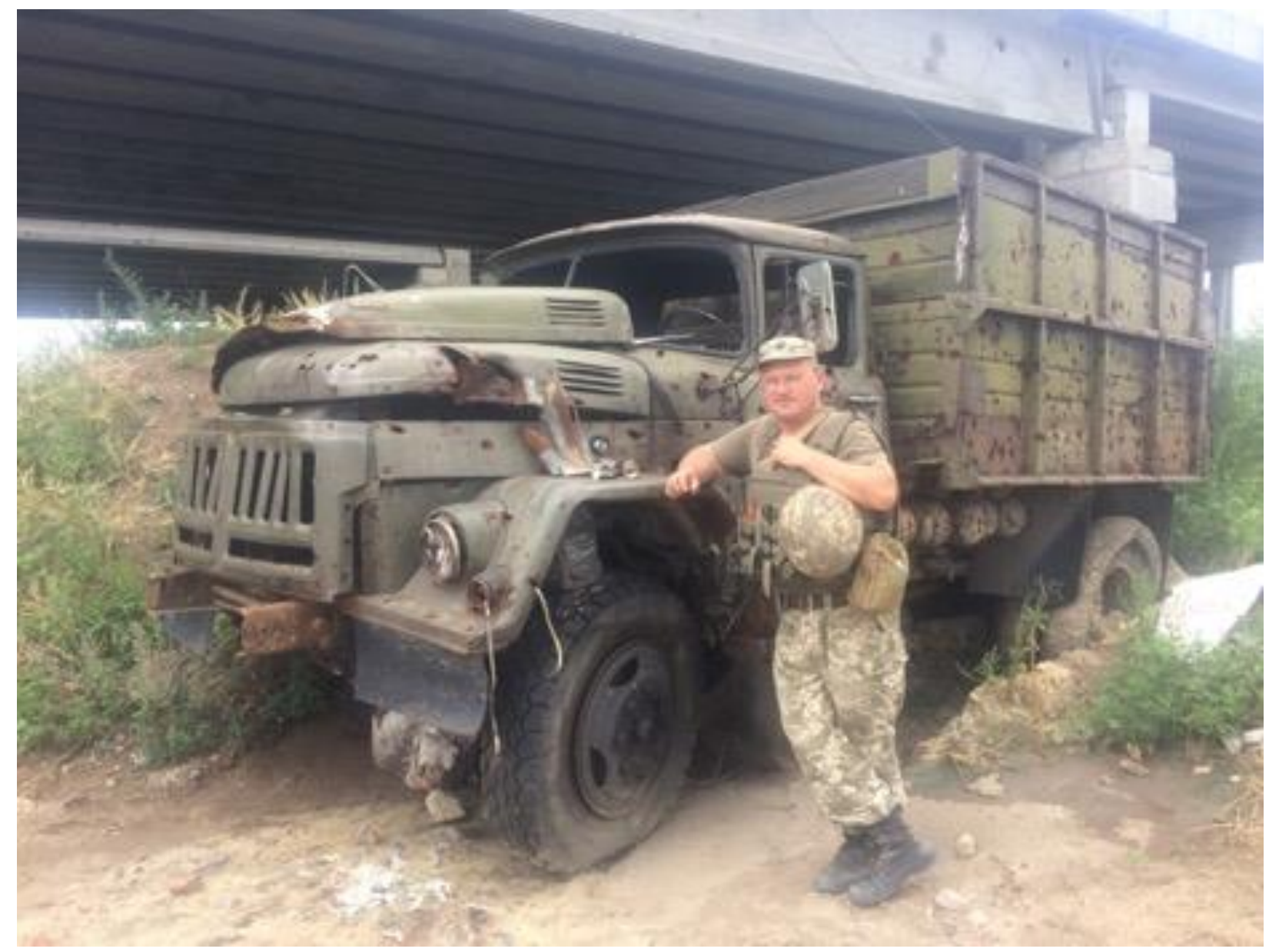

Figure 4. Commander of the checkpoint Ivan Ivanovich and the truck that he preserves as a memorial object (Credit: author). 


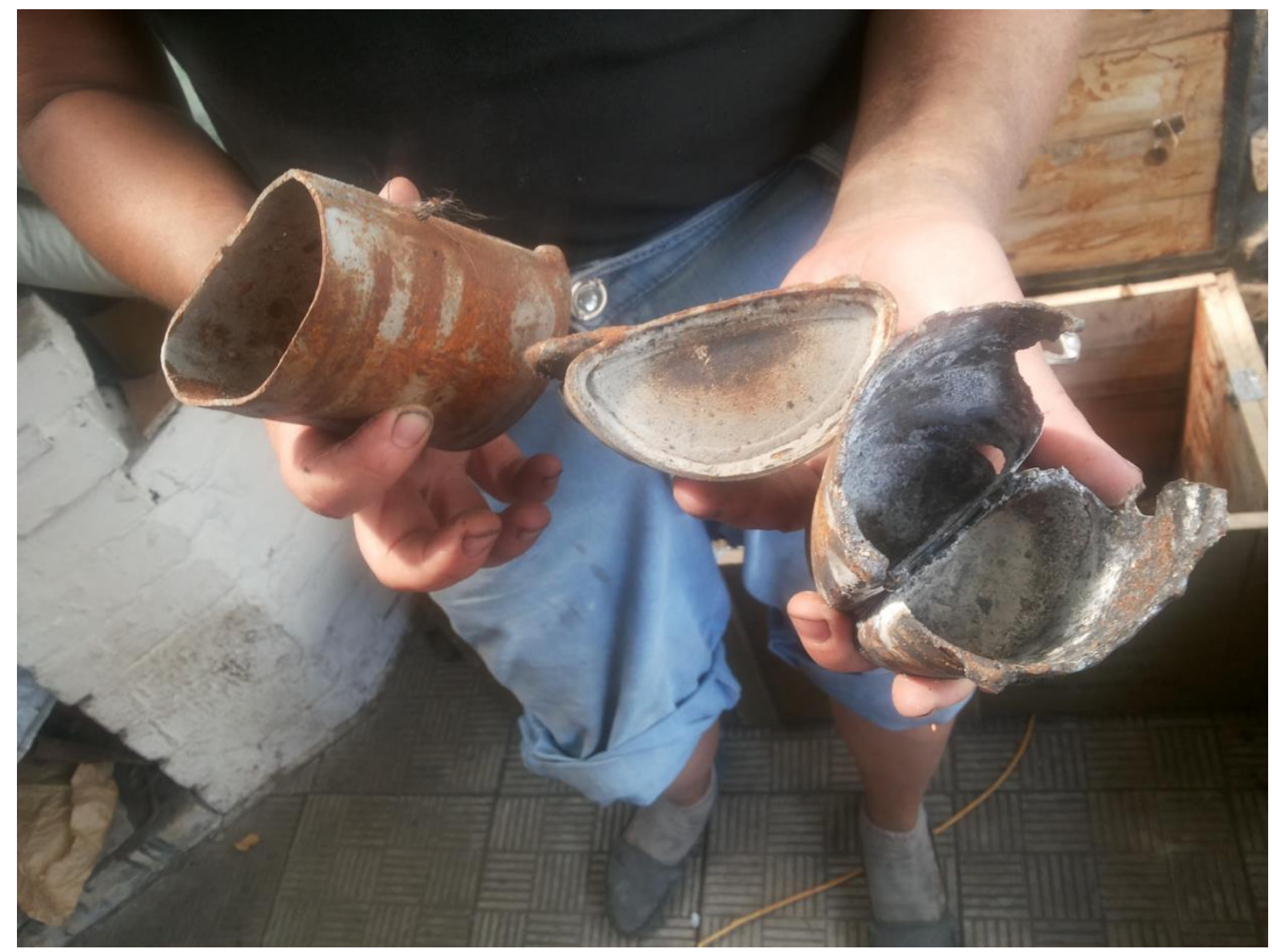

Figure 5. Pieces of armament preserved as an evidence of alleged war crimes (Credit: author). 
SOPOVA - THE DEATH COLLECTORS: THE MATERLAL CULTURE OF W AR AS A MEANS OF RECLAIMING AGENCY IN EASTERN UKRAINE

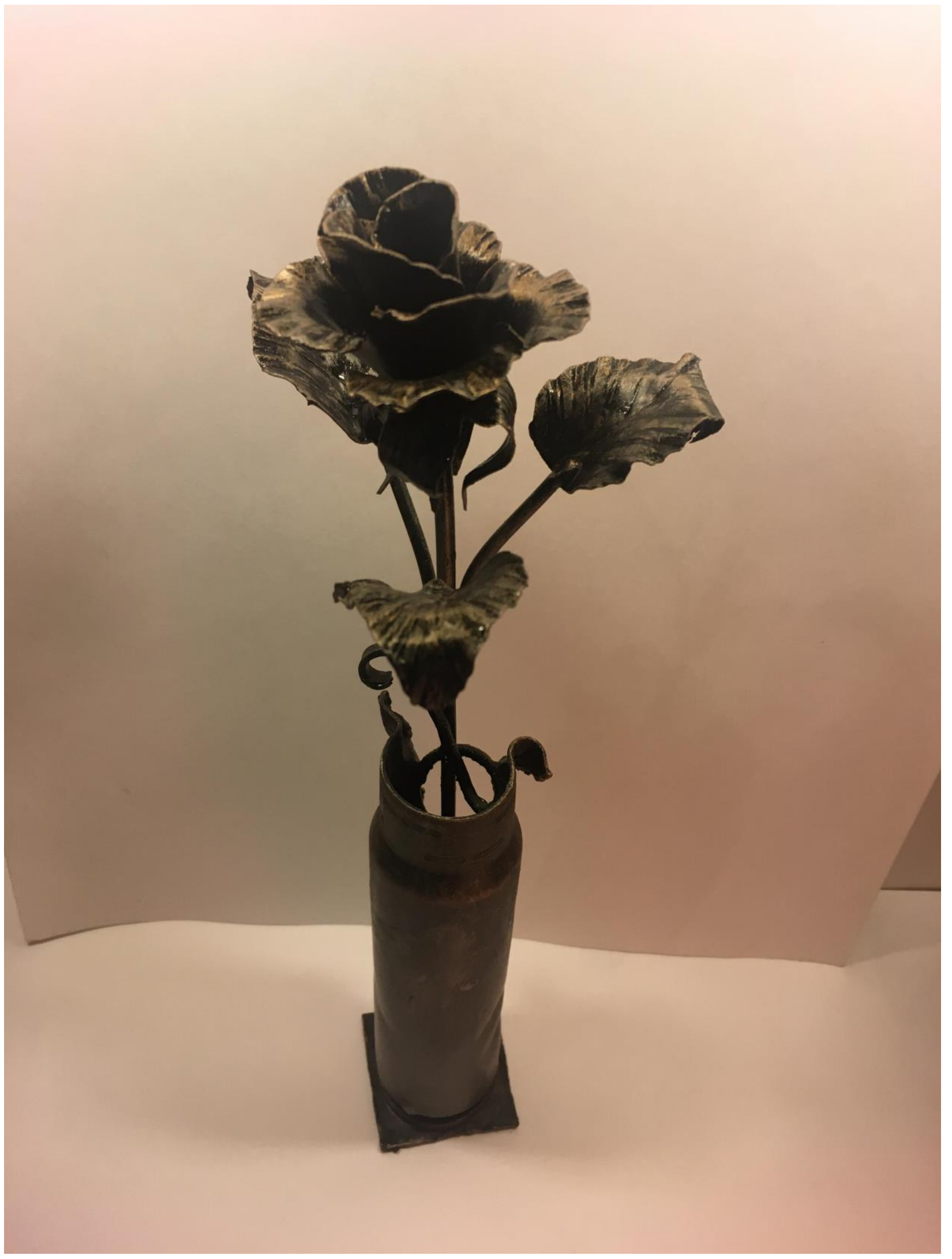

(C) School of Slavonic and Eastern European Studies, University College London, 2019. 
Figure 6. A handmade souvenir from Donetsk, a shell case with a metal rose 'growing' out of it (Credit: Nataly Veremeeva).

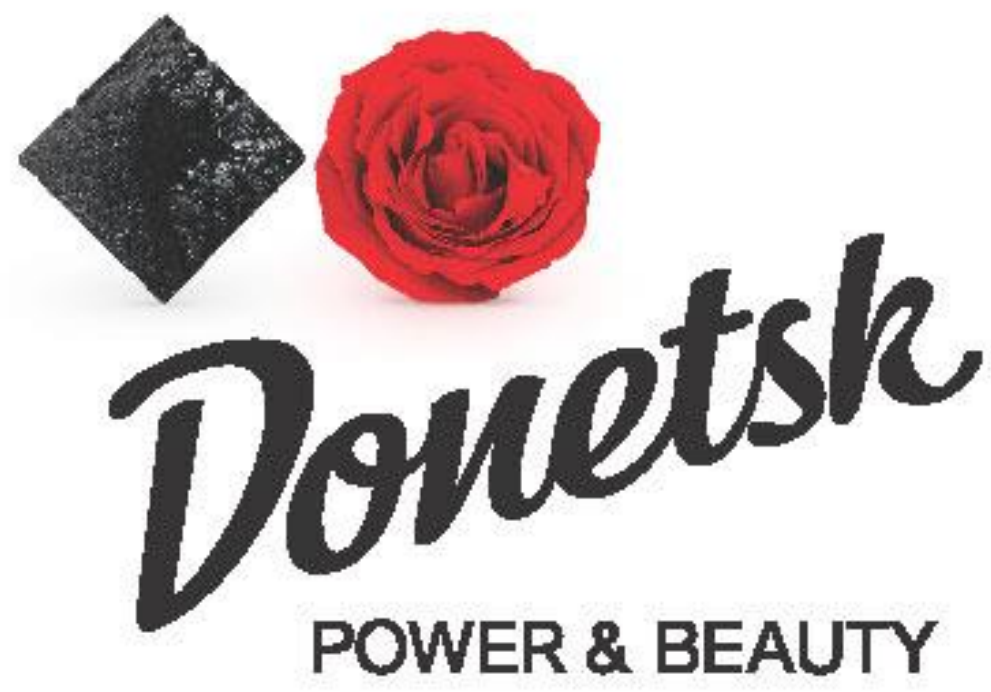

Figure 7 - Emblem of the city of Donetsk developed two years before the outbreak of war (Credit: Department of Urban Landscaping and Public Amenities of Donetsk City Council). 


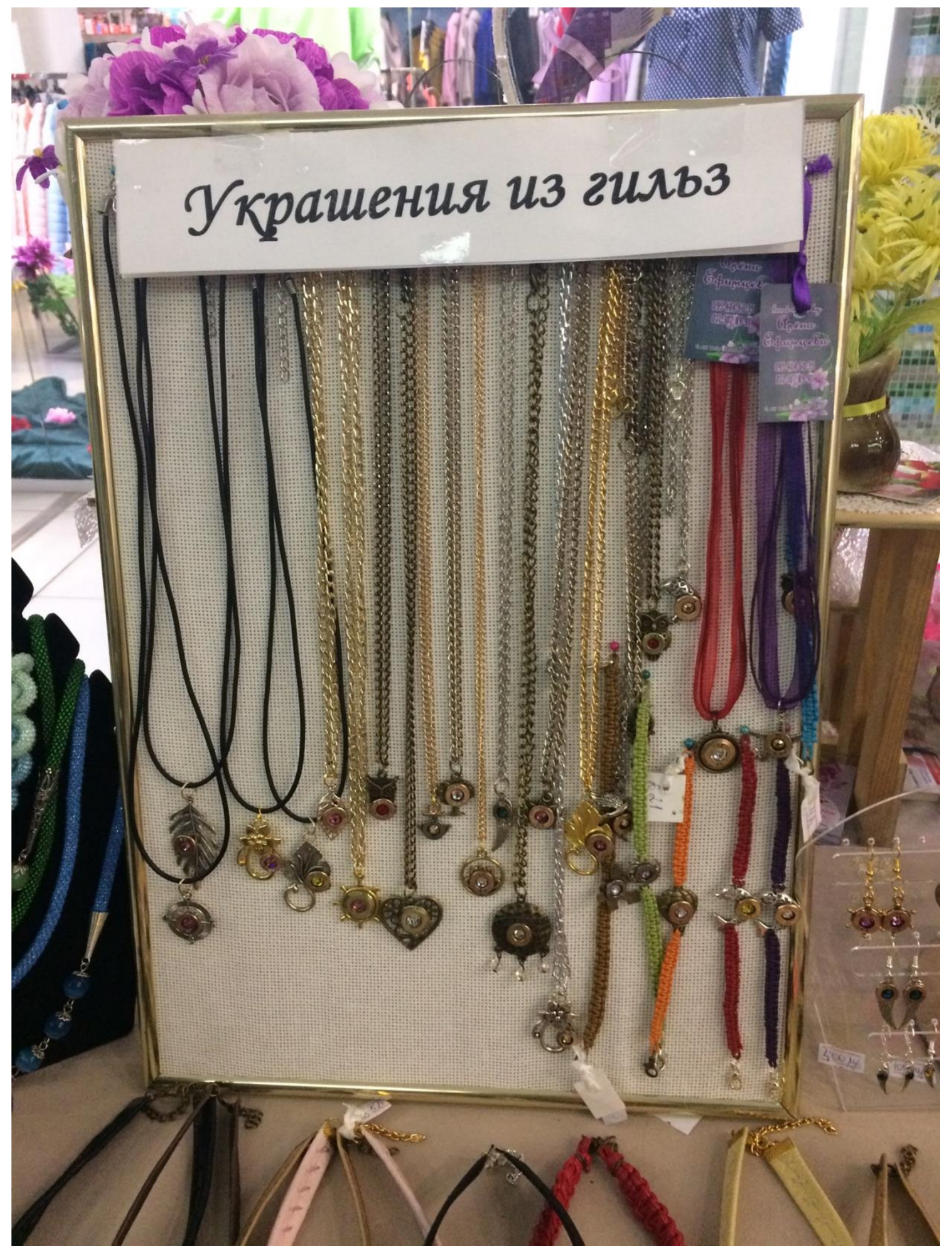

Figure 8. Jewellery made of bullet cases at the handmade fair in Donetsk (Credit: author). 


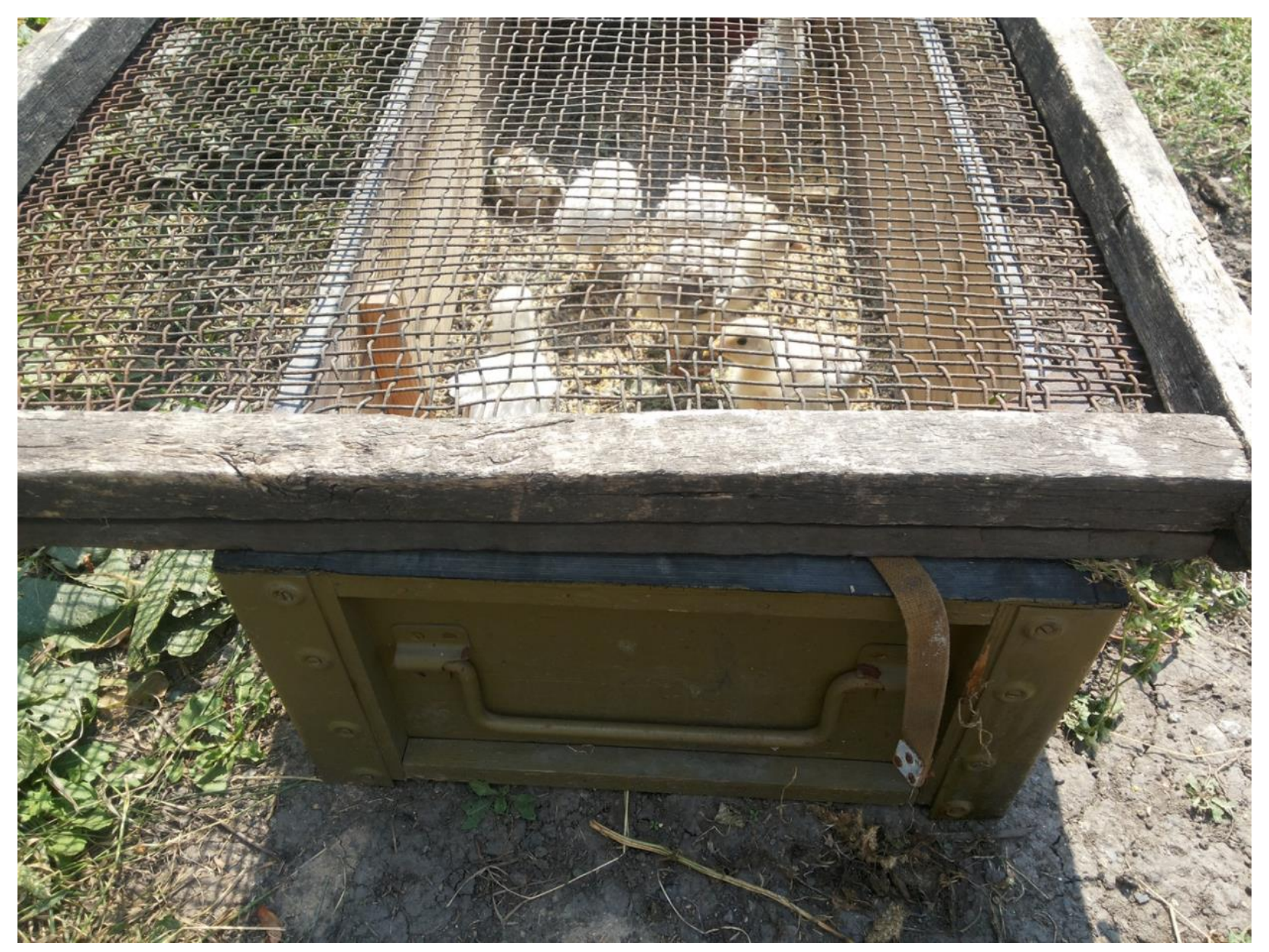

Figure 9. Weaponry box being used as a chicken cage in the household in village of Nikishino (Credit: author). 


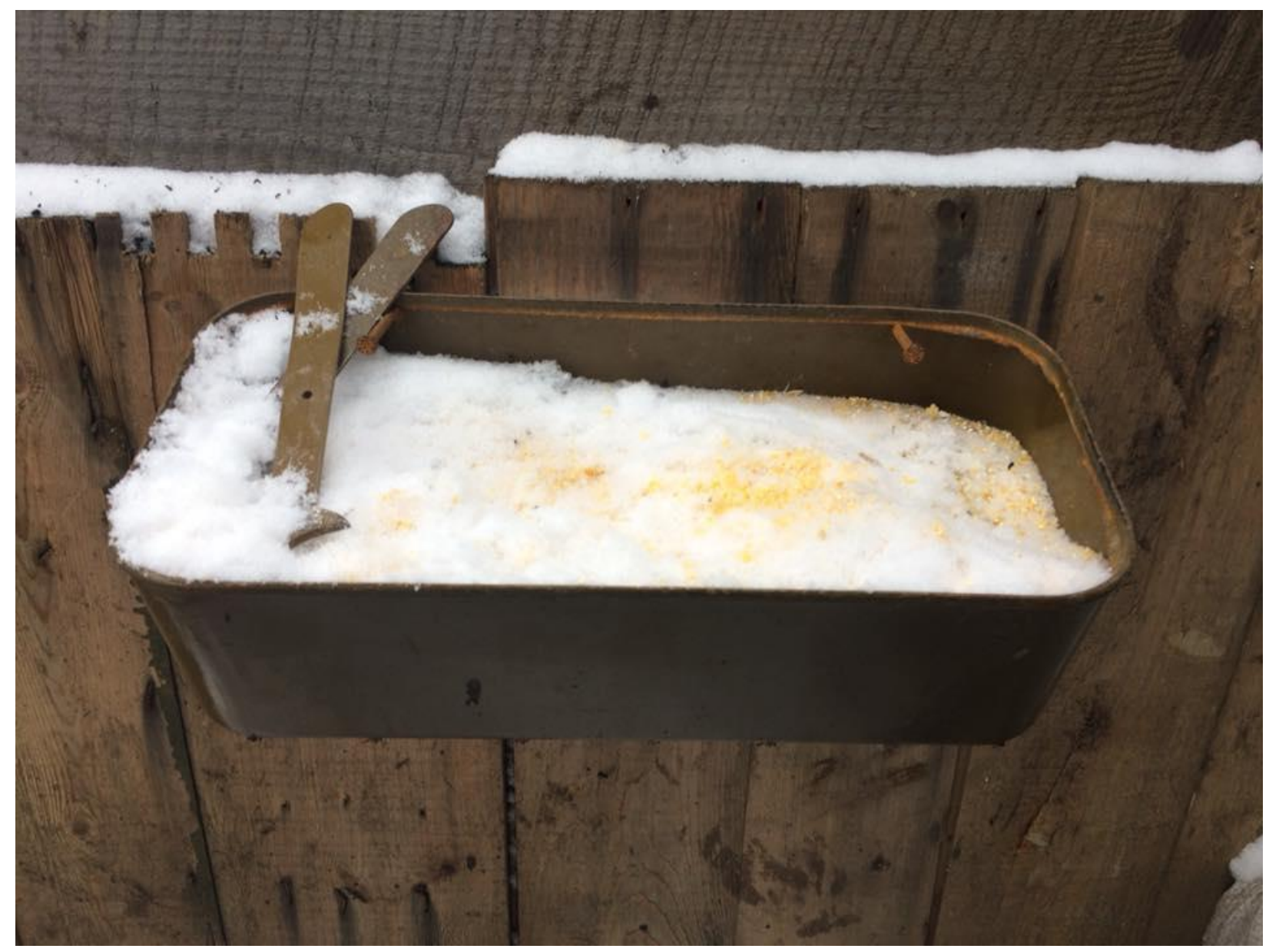

Figure 10. A bird feeder made out of a bullet container at the military position near Donetsk (Credit: author).

\section{References}

Primary Sources:

Manufacturer, Splav Rocket, Reaktivnaia sistema zalpovogo ognia «Grad» (2016),

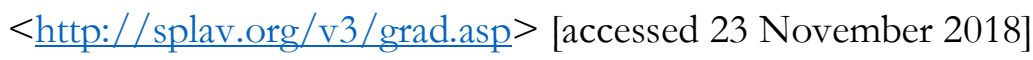

OSCE Special Monitoring Mission to Ukraine, Civilian casualties in eastern Ukraine 2016 (2017), $<\underline{\text { https://www.osce.org/special-monitoring-mission-to- }}$ ukraine/342121?download=true $>$ [accessed 23 November 2018] 
Secondary Sources:

Beckstead, Zachary, and others, 'Collective remembering through the materiality and organization of war memorials', Journal of Material Culture, 16.2 (2011), pp. 193-213

Danet, Brenda, and Katriel, Tamar, 'Glorious obsessions, passionate lovers, and hidden treasures: collecting, metaphor, and the romantic ethic', in The Socialness of Things: Essays on the SocioSemiotics of Objects, ed. By Stephen Harold Riggins (Berlin, New York: Mouton de Gruyter, 1994), pp. 23-62

Gygi, Fabio, 'Shattered experiences-recycled relics: Strategies of representation and the legacy of the Great War', in Matters of Conflict, ed. By Nicholas Saunders (New York: Routledge, 2004), pp. $72-89$

Kirianov, Igor, 'Klassifikatsia, printsipy otbora I vyiavleniya pamiatnikov trudovoi slavy sovetskogo naroda', paper delivered at the conference 'Pamiatniki trudovoi slavy sovetskogo naroda', Gorky, 1979

Maček, Ivana, Sarajevo under siege: Anthropology in wartime (Philadelphia: University of Pennsylvania Press, 2009)

Moshenska, Gabriel, 'A hard rain: children's shrapnel collections in the Second World War', Journal of material culture, 13.1 (2008), pp. 107-125

Miheieva, Oksana, 'Derzhavna ideolohiya ta konstruyuvannya spil'noyi pamyati pro mynule: orhanizovane zabuttya ta fenomen pryhaduvannya (na prykladi pamyatnykiv Donetska)', paper delivered at the conference 'Suchasni suspilni problem u vymiri sotsiolohiyi upravlinnya' (Donetsk National University, 14 April 2006) 
Nordstrom, Carolyn, $A$ different kind of war story (Philadelphia: University of Pennsylvania Press, 1997)

Pearce, Susan, An investigation into collecting in the European tradition (London: Routledge, 1995)

Saunders, Nicholas, 'The ironic 'culture of shells' in the Great War and beyond', in Matériel Culture: The Archaeology of Twentieth-Century Conflict, ed. by John Schofield, William Gray Johnson and Colleen Beck (London: Routledge, 2002), pp. 22-40

Saunders, Rebecca, 'Tell the truth: the archaeology of human rights abuses in Guatemala and the former Yugoslavia', in Matériel Culture: The Archaeology of Twentieth-Century Conflict, ed. by John Schofield, William Gray Johnson and Colleen Beck (London: Routledge, 2002), pp. $103-114$

Schofield, John, 'Monuments and the memories of war: motivations for preserving military sites in England', in Materiel Culture: The Archaeology of Twentieth-Century Conflict, ed. by John Schofield, William Gray Johnson and Colleen Beck (London: Routledge, 2002), pp. 143158

Stanbridge, Andrew, 'UXO in Laos: A Multifaceted Look at Bombs from the Secret War Era', Anthropology Now, 3.2 (2011), pp. 48-61

This work is licensed under the Creative Commons Attribution-NonCommercial-ShareAlike 3.0 Unported License. To view a copy of this license, visit http://creativecommons.org/licenses/bync-sa/3.0/ or send a letter to Creative Commons, PO Box 1866, Mountain View, CA 94042, USA. 